DOI: $10.24193 /$ tras.61E.5

Published First Online: 10/28/2020

\section{FORMATION OF NATIONAL}

\section{POSITIONS ON EU LEGISLATIVE}

PROPOSALS IN SLOVENIA:

WHAT ROLE FOR CIVIL SOCIETY

ORGANIZATIONS?

\author{
Damjan LAJH \\ Meta NOVAK
}

\section{Damjan LAJH}

Associate Professor and Jean Monnet Professor, Ph.D., Faculty of Social Sciences,

University of Ljubljana, Ljubljana, Slovenia

Head of the Centre for Political Science Research,

Faculty of Social Sciences,

University of Ljubljana, Ljubljana, Slovenia

Tel.: 00386-0-1-5805.227

E-mail:damjan.lajh@fdv.uni-lj.si

\section{Meta NOVAK (corresponding author)}

Assistant Professor, Faculty of Social Sciences, Ph.D., University of Ljubljana, Ljubljana, Slovenia

Researcher, Centre for Political Science Research, Faculty of Social Sciences,

University of Ljubljana, Ljubljana, Slovenia

Tel.: 00386-0-1-5805.227

E-mail: meta.novak@fdv.uni-lj.si

\section{Abstract}

This article considers the EU policymaking process from the national perspective, emphasizing the involvement of civil society organizations (CSOs) in the process of formulating national positions prior to negotiations in the Council of the EU. Its scope is limited to the stagist model of policy analysis, focusing on the policy formulation stage and 20 of the most salient EU legislative proposals on the EU agenda between 2008 and 2010. It is argued that Slovenia seems to neglect the expertise and information held by CSOs during the process of forming national positions. The current system for coordinating EU affairs anticipates only a narrow role for CSOs. The national position is typically formed at a lower bureaucratic level and based on the European Commission's proposal. While national officials recognize the benefits of including CSOs in the whole process, they are afraid of greater work, more bureaucratic processes, and corruption.

Keywords: EU policymaking, coordination of EU affairs, formulating national positions, civil society organizations, representation, Slovenia. 


\section{Introduction}

When thinking about policymaking, we initially consider the question of jurisdiction - what the government has decided to do or not to do (Dye, 1972). However, the recent globalization and Europeanisation processes mean there is often more than one source of authority available. Probably the clearest case of the intertwined relationship of national and supranational policymaking perspectives is the European Union (EU). Successful participation in EU policymaking requires Member States to effectively formulate national positions prior to negotiating in the Council of the EU. Preparing strong and convincing national positions is an important challenge in terms of their efficiency and democratic legitimacy. In this article, we are thus interested in characteristics of the EU policymaking process from the national perspective, especially the involvement of 'civil society organizations (CSOs)' while formulating national positions before negotiations begin in the Council of the EU.

EU policymaking never takes place in a vacuum, but instead in the context of multiple locations where policy issues are addressed, namely local to global levels and involving both formal and informal processes (Wallace, 2010, p. 90). With power divided vertically and horizontally, EU decision-making is affected by the combination of the multitude of access points and the demanding rules of governing decision-making process (Princen, 2009, p. 40), requiring that any differences between domestic and EU policymaking settings be overcome by streamlining and adapting national actions to the sectoral divisions and 'rhythm' of the EU policy process (Gärtner, Hörner and Obholzer, 2011, p. 80). Observations of EU policymaking must consider the multilevel setting of the EU. In many policy sectors, the EU is an essential - if not the most important - decision-making venue where governments play for high stakes. Decisions taken in Brussels can have far-reaching consequences for the Member States. Therefore, it is no surprise that at least in some policy areas there is particularly intense pressure on governments to effectively coordinate their activities with respect to EU policymaking (Kassim, 2001, p. 9; Fink-Hafner, 2007; Žurga, 2018). As such, national political institutions are vital components of the EU's institutional architecture. According to Wallace (2010, p. 89), national actors play important and influential roles at all stages of the EU policy process. Of course, the roles held by these actors here vary slightly from those they perform at the national level. National ministers, for example, sit together in the Council and have an important role in adopting legislation, albeit one where they represent their own interests and those of their constituents (Young, 2010, p. 50). Special importance is given here to the formation of national policy preferences and positions. Participation in the Council calls for coordination since meetings must be prepared and positions defended at different levels and across different sectors (Kassim, 2001, p. 10). However, the forming of national policy preferences does not take place in splendid domestic isolation, but is also subject to exogenous pressures (Kassim, 2001, p. 10), especially from various organized interests. However, opportunities for access and influence are not evenly 
distributed within Member States (Wallace, 2010, p. 89), forcing organized interests to seek different channels beyond the state ${ }^{1}$ to influence the EU-level decision-making by way of either direct access to EU institutions or via institutionalized bodies (i.e., the Economic and Social Committee and Committee of the Regions).

Learning how to manage this extra dimension of national public policy has in the past 50 years been a key challenge for national governments (Wallace, 2010, p. 89). Especially the new Member States from Central and Eastern Europe face several specific domestic challenges that impede the efficient coordination of and effective participation in the policymaking process: a shortage of resources and expertise concerning EU affairs, financial constraints, the lack of certain skills among civil servants (i.e., insufficient knowledge of the formal/ informal working mechanisms and rules of EU policymaking, deficient language skills), the politicization of the bureaucracies, all occurring while governments (often coalitions) in those countries regularly change (Gärtner, Hörner and Obholzer, 2011, pp. 80-82), leading to frequent (institutional) alterations in how EU affairs are coordinated at the domestic level.

In our analysis we focus on the case of Slovenia. We believe Slovenia is a good selection among newer Member States when looking at the inclusion of CSOs in EU policymaking from the (bottom-up) perspective of national administrations. Slovenia is a new democracy with a socialist past, a newer member often characterized as 'a good student' (Fink-Hafner and Lajh, 2008). Further, it is a small state with modest resources (Krašovec and Lajh, 2010), and a country with a vibrant civil society (Črnak-Meglič and Rakar, 2009, p. 240). With this study we want to contribute to the question how national positions are formed prior to starting negotiations in the Council from the perspective of the role of $\mathrm{CSOs}^{2}$ in the domestic public sector, i.e. in the process of domestic coordination of EU affairs.

The article uses varied methodology from secondary analysis of legislation that define the coordination of EU affairs in Slovenia, a survey conducted among national officials at Slovenian ministries working in the area of EU affairs (MZZ, Directorate for EU Affairs), analyses of two Stakeholder meetings (2015a, 2015b) and interviews conducted among national officials that cooperated in the preparation of national positions on the 20 most salient EU directive proposals (www.intereuro.eu; also see Beyers et al., 2014).

After the introductory section, the article is structured as follows. The second section offers an overview of the current coordination of EU affairs in Slovenia and

1 The practical reality of a huge number of organised interests within the EU is that, if they are to influence public policy in their sector, they need to act cross-nationally and get themselves to Brussels (Richardson, 2006, p. 232).

2 In this article, we define CSOs very broadly, considering the European Commission's definition as including 'the trade unions and employers' organisations ('social partners'); nongovernmental organisations; professional associations; charities; grass-roots organisations; organisations that involve citizens in local and municipal life with a particular contribution from churches and religious communities' (European Commission, 2001, p. 14). 
the ways CSOs are included in this process. The third section relies on survey data to analyze the inclusion of CSOs in formulating the national position regarding EU legislative proposals. Finally, the fourth section summarizes the main findings and evaluates how the Slovenian political system has been adapted to EU policymaking.

The article argues that coordination of EU affairs in Slovenia does not anticipate the participation of CSOs in preparing national positions towards EU proposals. In this way, the expertise and information held by CSOs are neglected. Although national officials recognize the benefits of CSOs' inclusion in preparation of national positions, they also have reservations since they are afraid they would be overburdened, this will lead to more bureaucratic work and that such participation may lead to corruption and non-transparent practices. The national position is typically formed at a lower bureaucratic level and based on the European Commission's proposal.

\section{Forming national positions on proposed EU legislation in Slovenia: limited access for CSOs?}

CSOs can be relevant actors in the practice of forming national positions vis-à-vis EU legislative proposals. They can make the policymaking process more efficient since CSOs often encompass relevant information and expert opinions lacking among national officials and ensure the citizens' participation in the whole process (Saurugger, 2008, pp. 1276-1277). The ways CSOs are included in formulating national positions on EU legislation often depend on a particular country's system for coordinating EU affairs. After joining the EU, Slovenia has started actively participating in forming EU policies and legislation. Consequently, this aspect of EU affairs becoming part of domestic policies demanded changes be made to Slovenia's political system. The newly established relationship between the Slovenian and EU political systems was defined by amendments to the Constitution introduced in $2003^{3}$. A year later (in March 2004), the National Assembly - government relationship in decision-making on EU affairs was codified ${ }^{4}$. The executive branch took over the role of representing and arguing Slovenia's position in EU institutions. The National Assembly, in contrast, is included in formulating the national position regarding EU affairs ${ }^{5}$.

EU membership was a turning point in the development of coordinating EU affairs at the Slovenian national administrative level. Following the initial polycentric stage, the coordination of EU affairs began to exhibit tendencies towards centralization.

3 The constitutional amendment, represented by Article 3.a, allows for the delegation of execution of some sovereign rights to international organisations, provided that: a) these international organisations are based on the observation of human rights and fundamental freedoms, democracy and the rule of law; and b) the international treaty which sets down this delegation is ratified by the National Assembly of the Republic of Slovenia by a two-thirds majority vote (see UZ3a, 47, 68 2003).

4 See the Act on Cooperation between the National Assembly and the Government in EU Affairs.

5 For a more detailed analysis of the aforementioned political system adaptations, see Fink-Hafner and Lajh, 2005, pp. 82-86. 
It started with the establishment of the 'Government Office for European Affairs (GOEA)' (at the end of 1997), led by a minister without portfolio, and the formation of the Negotiating Team of the Republic of Slovenia for Accession to the EU (Fink-Hafner, 2007, pp. 818-819). In the period of EU membership (coinciding with the change of government in autumn 2004), the central political coordination point in the hierarchy of the domestic management of European affairs shifted towards the Prime Minister, where it was finally consolidated during Slovenia's Presidency of the Council of the EU (Lajh, 2010). Following Slovenia's formal entry to the EU, EU affairs then became 'internalized' as a domestic matter. This process impacted the majority of officials at the national level, although the shortage of 'European specialists' in Slovenia's relatively small administration was quite evident during the phase of Slovenia's accession to the EU and has also continued in the country's EU membership (Lajh, 2012). The problem of limited staff became especially acute during Slovenia's Presidency of the Council of the EU (Fink-Hafner and Lajh, 2008). It is also noteworthy that a considerable share of so-called EU staff/ specialists have moved to either EU institutions or the Permanent Representation of the Republic of Slovenia to the EU in Brussels.

Member States have very different systems in place for coordinating EU affairs (Fink-Hafner, 2007, p. 805). It is characteristic for new Member States from Central and Eastern Europe that the coordination of EU affairs is not yet permanently established and often changes (Dimitrova and Toshkov, 2007). Following the alteration of Slovenia's administrative system for coordinating EU affairs in 2004, a new change came in 2012 - the abolition of the GOEA and transformation of its tasks and most staff to a special directorate within the Ministry of Foreign Affairs (which again coincided with a change in government in the spring of 2012). The relationship towards EU institutions is defined in chapter 6.4 of the Government's Rules of Procedure. The current system for coordinating EU affairs in Slovenia entails the cooperation of the following actors: (a) the Government; (b) the Central Coordination Unit at the Ministry of Foreign Affairs; (c) the Permanent Representation in Brussels; (d) working groups that prepare national positions in response to EU legislative proposals; (e) working groups for EU affairs; and (f) the National Assembly. The central coordination unit was taken over by the Ministry of Foreign Affairs. Specifically, the Directorate for EU Affairs ensures the procedurally correct preparation and submission of national cross-sectoral alignment positions on EU proposals that are decided on later at the Council of the EU by working groups, committees and ministerial meetings (Rules of Procedure of the Government of the Republic of Slovenia, 2014; MZZ, Coordination of European Affairs, 2016). The ministry responsible for EU affairs tasks the competent ministry or governmental office with preparing the national position regarding particular EU legislation and, via a special government resolution, it designates the participating ministries and competent working groups. The preparation and endorsement of the national position takes place in the government information system, the so-called EU portal. The EU portal's functioning is assured by the Ministry of Foreign Affairs (Article 49.d, Rules of 
Procedure of the Government of the Republic of Slovenia, 2014). Cross-sectoral alignment positions emerge by way of cross-sectoral meetings, meetings of working groups for preparing a position, regular meetings of the Working Group for EU Affairs, led by the Ministry of Foreign Affairs, and meetings of the Group for EU Affairs (Article 49.g, Rules of Procedures of the Government of the Republic of Slovenia, 2014). The Ministry or a government agency prepare the Republic of Slovenia's draft position which is then considered and adopted by the Government. Positions on legislative proposals that, due to their content and according to the Constitution and national legislation, fall within the competence of the National Assembly are submitted to the National Assembly by the Secretary General of the Government also through the EU portal. The position is then discussed and considered by the Committee for EU Affairs and the responsible Working Committee (Article 49.h, Rules of Procedures of the Government of the Republic of Slovenia, 2014). The Slovenian position can be later amended or extended if substantial changes emerge in the process. Any changes are prepared by the Ministry or a government agency and adopted using the same procedure as for the first position (Article 49.i, Rules of Procedures of the Government of the Republic of Slovenia, 2014). Slovenian representatives ${ }^{6}$ participating in a meeting of the Council of the EU are obliged to advocate the national position previously published and confirmed on the EU portal (Article 49.p, Rules of Procedures of the Government of the Republic of Slovenia, 2014; MZZ, Position preparation procedure, 2016). Representatives must later report on the content of the meetings and the enforcement of decisions made by Slovenia in EU institutions (Article 49.r, Rules of Procedures of the Government of the Republic of Slovenia, 2014).

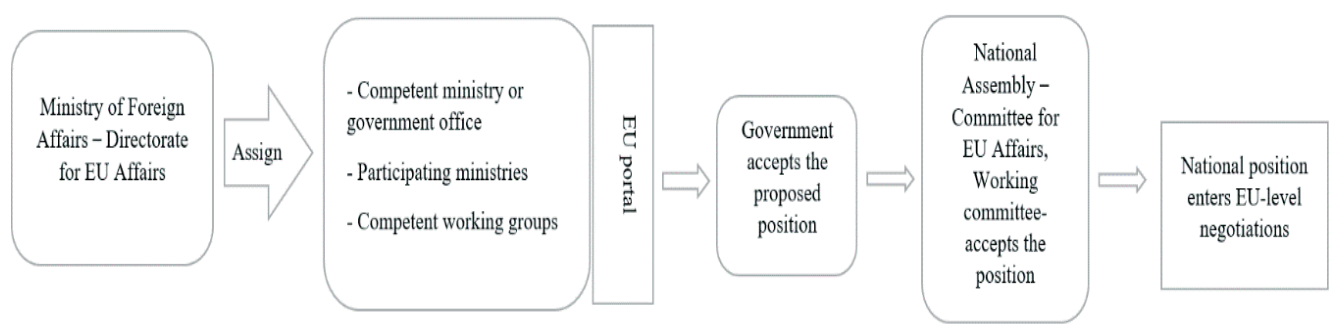

Figure 1: Coordination of EU affairs in Slovenia

Source: Authors

The process of forming the national position is relatively rigid, closed and does not allow CSOs near also because the EU portal where preparation of the national

6 Representatives of Slovenia are members of government, the state secretary, head of the Permanent representation in Brussels, his/her deputy, head of the government service, officials from ministries or government departments and the state attorney (Article 49.č, Rules of Procedure of the Government of the Republic of Slovenia, 2014). 
position occurs is closed to both the public and CSOs (Stakeholder meeting, 2015a; 2015b). Recently, some minor changes were made. Since June 1, 2016, each ministry can decide whether to publicly release the materials discussed at governmental meetings or not. In this way, the EU portal has also become accessible to civil society, but the scope is very limited: (1) the documents published are mostly national positions adopted at the governmental session, by which time is already relatively late to allow the more meaningful inclusion of civil society; (2) only a share of civil society representatives are informed about the change; and (3) it is mostly ministries that are already open to civil society that publish such documents ${ }^{7}$. Consequently, civil society cannot provide feedback, comments or suggestions on the national position. According to the normative arrangement of the coordination of EU affairs, Slovenian CSOs are largely excluded from the process of forming national positions on proposed EU legislation ${ }^{8}$. Much depends on the individual engagement of competent authorities and policy officials. Neither legislation defining relations between the executive and the national parliament nor internal governmental acts concerning the coordination of EU affairs provide for any inclusive role for CSOs. Formal access to facilitate the cooperation of the interested public, i.e. also CSOs, is only defined generally and never specifically when it comes to EU affairs. Article 46 of the National Assembly's Rules of Procedure states that the working committee of the National Assembly, with the intention to gather information, may 'organize public hearings and invite experts and other persons who might provide useful information', but, again, this is only defined generally and not specifically relative to the EU. Another window of opportunity may be the 'lobbying approach' of CSOs in policymaking. However, here the inclusion of CSOs is constrained by the negative connotation attributed to lobbying in Slovenia. Lobbying activity is regulated by the Law on Integrity and Prevention of Corruption (ZIntPK, 2011), which provides:

'the activity of lobbyists who, on behalf of interest groups, engage in non-public efforts to influence on the decision-making of state bodies and local community bodies and holders of public authority while considering and adopting regulations and other general acts. (...) An act of lobbying is considered to be every non-public contact of a lobbyist with a lobbied person that aims to influence the content or the process of adopting the said decisions (ZIntPK, 2011)'?

7 Eight documents have been made public by the Ministry of Agriculture, Forestry and Food, five by the Ministry of Foreign Affairs and four each by the Ministry of Economic Development and Technology as well as the Ministry of the Interior and Ministry of Finance.

8 Although the Rules of Procedure of the Government of the Republic of Slovenia and the Resolution on Legislative Regulation anticipate the inclusion of the public, civil society, and experts in forming legislative acts and regulations, the role of the civil society is not explicitly defined when it comes to EU affairs (Rules of Procedure of the Government of the Republic of Slovenia, 2001; ReNDej, 2009).

9 In the literature, we may find different definitions of lobbying. Austen-Smith and Wright (1992) define lobbying as 'information transmission'. The idea is that lobbyists possess information that de- 
The definition of lobbying is thus closely connected with corruption and the strict regulation of lobbying activities ${ }^{10}$ discourages national officials from including CSOs in policymaking. Hence, CSOs require a proactive approach, entailing the use of different strategies (Beyers, 2002, p. 585) to influence decision-makers at either the bureaucratic or political level. The next section offers an overview of CSOs' inclusion in EU policymaking, followed by analyses of the forming of Slovenian national positions on proposed EU legislation and CSOs' role in these processes.

\section{Empirical evidence on the inclusion of CSOs in forming national positions on proposed EU legislation}

\subsection{Methodology}

For the purpose of our analysis, we consider the stagist model of policy analysis while focusing on the policy formulation stage, usually defined as the critical stage which reveals the key power relations among those involved in policymaking. This stage namely not only involves placing issues on the agenda, but is also closely linked to the search for alternative policy solutions (see Hogwood and Gunn, 1984; Parsons, 1995) and also represents a window of opportunity for the involvement of CSOs. The literature still appears to be deficient regarding how policy is formulated in those segments where supranational and national processes interlink. In this article, we are interested in one of these inter-linkages - the way national positions are formed prior to commencing negotiations in the Council, particularly the role played by national CSOs in these processes. In answering this, we focus on 20 of the most salient EU legislative proposals on the EU agenda between 2008 and 2010. We selected these EU legislative proposals according to their appearances in the mass media. We decided on policy-centered sampling and to include the most salient issues to ensure that lobbying would be entailed ${ }^{11}$ (Beyers et al., 2014). After all, much EU legislation is very technical and not of much public interest. Although our study looks at the case of Slovenia, the measure of saliency is not based on Slovenian national media sources because EU topics, especially issues relating to EU legislative proposals, are not sufficiently covered by Slovenian sources. We, therefore, selected proposals covered

cision-makers need but do not have. A lobbyist is prepared to exchange this information and to persuade a decision-maker to act in his/her interest. The process is not simple as there may be different interest groups with different interests. But Austen-Smith and Wright define the lobbying activity more positively, by stating: 'a legislator will on average make 'better' decisions with lobbying than without, and that the more important is an issue to a special interest group, the more likely is the legislator to make the correct full-information decision' (Austen-Smith and Wright, 1992, p. 229).

10 At the same time, the 'interest group' definition is also quite negative by directly connecting an interest group's activity with lobbying and limiting it to lobbying by stating that an 'interest organisation is a legal entity of private law or another unregulated form of the association of natural or legal persons on behalf of and for whose account a lobbyist is performing lobbying activity' (ZIntPK, 2011).

11 If we had used a simple random sample of EU-level legislation, this may have resulted in highly technical proposals that could mean the mobilisation of fewer or zero CSOs. 
by at least one European source (Agence Europe or European Voice) and by at least two non-Slovenian national sources (Frankfurter Allgemeine Zeitung, Le Monde or Financial Times ${ }^{12}$. The analysis is based on mixed-methods research whose empirical part includes a secondary analysis of relevant national legislation, quantitative and qualitative analysis of 35 face-to-face interviews conducted with national officials, and analysis of stakeholder meetings held in 2015. The empirical part also includes analysis of interviews with key actors involved in preparing national positions on EU legislation as part of the project 'Improving consultation practices in decision-making on EU affairs at the national level' carried out in 2015 by the Ministry of Foreign Affairs, Directorate for EU Affairs. Empirical data covering the period 2008-2015 concern the formation of national positions prior to negotiations in the Council, especially the role of CSOs in these processes, also considering certain relevant recent reforms since then. It is particularly important to investigate this period because it includes the second and third government terms during Slovenia's full EU membership, enabling a discussion of the research problem following initial adaptations of the Slovenian political system to fit in with the established coordination of EU affairs that were later consolidated after Slovenia's Presidency to the Council of the EU in 2008.

\subsection{Results}

The normative arrangement for coordinating EU affairs in Slovenia described in the second section can deviate from practice. The analysis of our interviews with national officials shows the official national position on an EU legislative proposal is chiefly formulated at a lower bureaucratic level. The official responsible for responding to a legislative proposal formulates the first draft of the national position. In some cases, national positions have also been drafted during inter-departmental/ ministerial coordination if the proposed legislation exceeds the jurisdiction of one ministry. Only very rarely is formation of the national position based on government - national parliament exchanges or almost never in working groups with stakeholders. Only one ministry (Ministry of Agriculture, Forestry and Food) regularly organizes consultations with national stakeholders regarding EU affairs, and two ministries arrange such consultations quite regularly. Formal consultations like meetings and conferences as well as informal consultations such as telephone calls and emails are used (MZZ, Directorate for EU Affairs, 2015).$^{13}$ A lot depends on how an individual official prepares and leads the process of preparing a position (Stakeholder meeting, 2015b). The national position is in fact formed at a low bureaucratic tier by officials at a professional level of the line ministry responsible for formulating the national position.

12 After the sampling, we crosschecked the presence of selected EU legislative proposals in the Slovenian national daily newspapers Delo and Dnevnik. 19 of 20 legislative proposals were mentioned in at least one of these newspapers, showing these issues were also salient in Slovenia.

13 In March 2015, the Directorate for EU Affairs at the Ministry of Foreign Affairs conducted a short survey among ministries on advisory practice concerning EU affairs. The response rate was $100 \%$. 
This national position is thus formed in such a way that officials do not have problems and the position is sufficiently general to contain enough space for negotiating in the Council (Stakeholder meeting, 2015a). Something similar has been noticed, for example, among Dutch public officials, especially in less Europeanised policy sectors. Amidst the absence of any clear political position or political leadership, they prepare the national position themselves based on the last known political position. This may also mean opposing the EU legislative proposal than supporting it to ensure enough negotiation power in the Council (Geuijan and Hart, 2010).

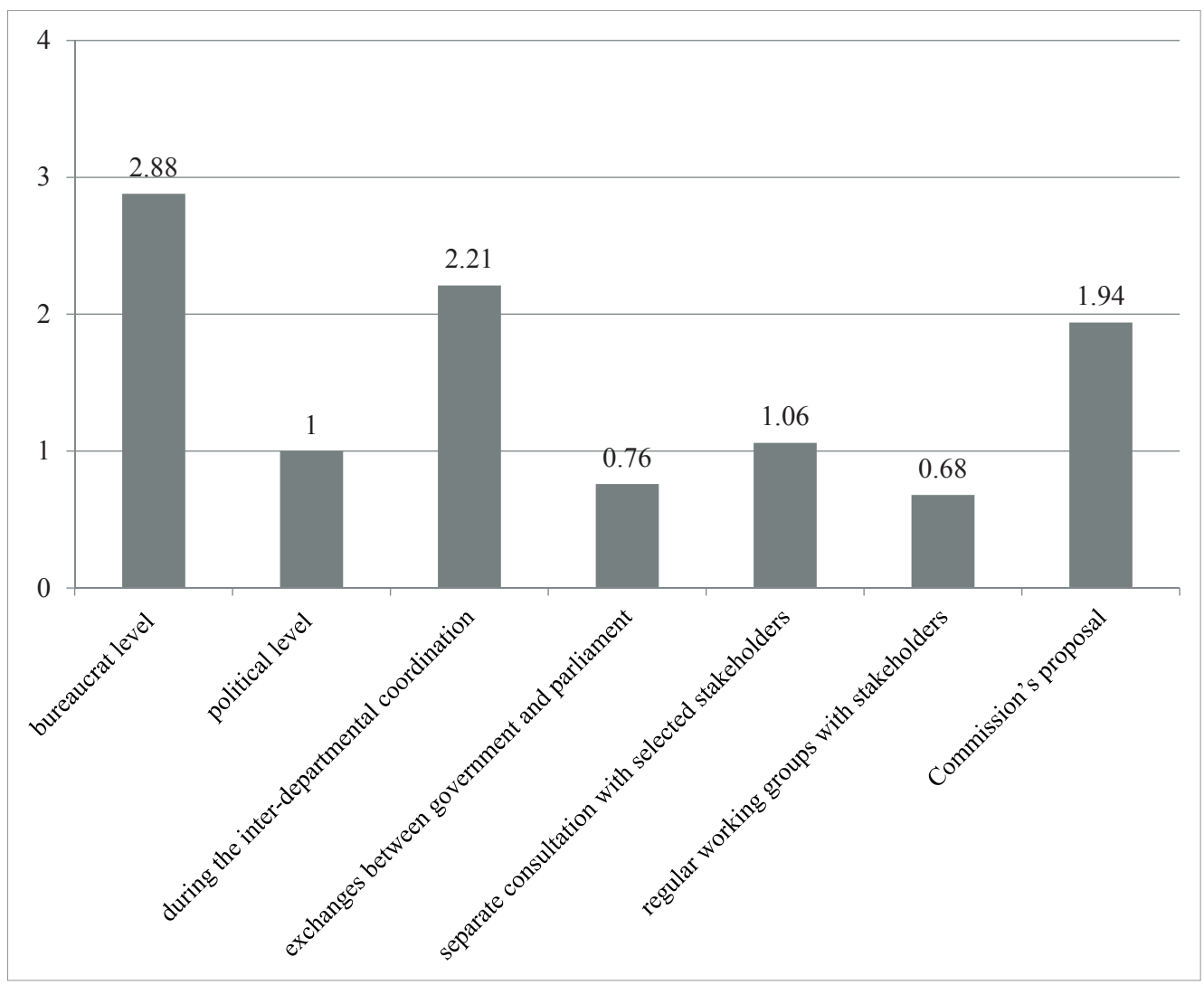

Figure 2: Crucial practices in the formulation of a national position (mean values, 1 - strongly disagree, 5 - strongly agree)

Source: INTEREURO survey, 35 interviews with national officials

The draft national position is often entirely based on the Commission's proposal. In fact, regarding the 20 proposed directives in the sample, the national position always supported the acceptance of the EU's proposal legislation. The possible objectives were to remain general and derived from the ambition to involve the fewest changes to the national legislation as possible. The officials were inclined to propos- 
als that only minimally altered national legislation. This has led to Slovenia's 'reputation' as 'a country with no opinion' (Stakeholder meeting 2015a). Especially during the Presidency, Slovenia consciously avoided taking a position, which probably put an end to the chances of domestic CSOs in the country influencing EU policymaking.

The same national position with hardly any changes is afterwards adopted by the whole ministry involved and the government. For national positions that must be submitted to the National Assembly, the Committee for EU Affairs discusses the position. Analysis of reports about such discussions in the sample of 20 national positions on EU legislative proposals reveals they are quite short, with questions being more the exception than the rule and the position usually being accepted without changes also due to the time pressure in the process (Stakeholder meeting, 2015a). The National Assembly does not have a position of its own (in the cases in the sample), but according to the procedure becomes acquainted with the national position and accepts it. The result of the current locus of forming the national position is that the very position formed at the professional level in the line ministry also enters the EU legislative process. It is no surprise that national officials rank the line ministry as the authority with the greatest influence on how the national system for coordinating EU affairs functions, followed by the Permanent Representation Office in Brussels, and only later by the government, the GOEA (until 2012) and the National Assembly. Although the role of the National Assembly as a representative institution is very weak despite its official task of approving the national position, it should not be overlooked when it comes to informing the public and voters. All governmental and parliamentary documents on proposed EU legislation are available at the National Assembly's official website. ${ }^{14}$ This is particularly important as government sessions are closed to the public. However, after such sessions the government holds press conferences and publishes press releases that summarize the conclusions of those government meetings and, as mentioned, since June 2016 some documents are made public.

Considering that national positions formed in the line ministry at a professional level almost without any changes enter negotiations with the Council of the EU, the expertise of CSOs would be a valuable input. In fact, almost all ministries believe that consultations with CSOs would be useful to ensure the formulation of well-considered national positions (MZZ, Directorate for EU Affairs, 2015). Similarly, officials at the European Commission agreed that it is important to include civil society and thus maintain a relationship with them in order to receive specific and technical information (Koeppl, 2001). Despite the need for information, especially from experts in the field, consultations at ministries are not a regular practice when it comes to EU affairs. Why are officials restrained from organizing regular open consultations with civil society? First of all, they miss at least the minimum principles for state -

14 Access to EU-related documents at the National Assembly's website, [Online] available at http:// www.dz-rs.si/wps/portal/Home/deloDZ/zakonodaja/zadeveEvropskeUnije. 


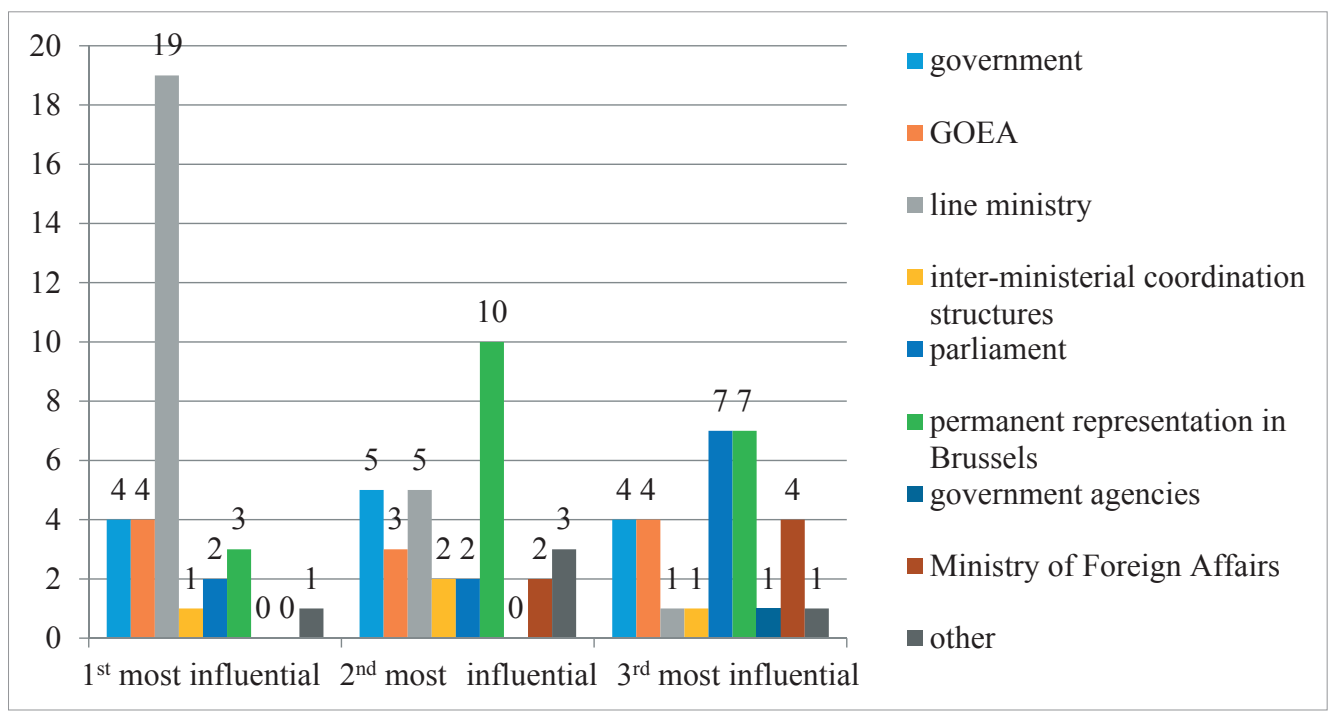

Figure 3: Crucial institutions for managing EU affairs (frequencies)

Source: INTEREURO survey, 35 interviews among national officials

non-state sector cooperation concerning EU affairs. Officials also express concern regarding the increased administrative work that such consultations would create due to staff shortages at the ministries, particularly in the timeframe given for preparing national positions, which is usually short and requires flexibility from officials. Additional new regulations on organizing consultation with regard to EU affairs could also lead to over-regulation. Some ministries also recognize they are not very familiar with EU legislation regarding the different forms of consultation and all would like to participate in training on consultation processes for EU affairs. Problems are also detected on the side of civil society, such as: insufficient knowledge of the political system and decision-making procedures, excessively high expectations for a Slovenian influence in negotiation processes, insufficient knowledge of legislative proposals, the lack of professionalism and expert knowledge among civil society, and the unresponsiveness of civil society actors. Last but not least, officials are afraid of lobbyist, partial and private interests that are out of step with common and general goals (MZZ, Directorate for EU Affairs, 2015).

While, on the one hand, the coordination of EU affairs in Slovenia does not foresee the inclusion of CSOs in forming national positions, on the other, CSOs remain passive in their activities. This is in line with assessments that civil society in Central and Eastern Europe remains weak (Börzel, 2010, p. 4). CSOs are unresponsive, even when ministries invite them to comment on proposed EU legislation (Stakeholder meeting, 2015a; 2015b). The lack of various CSOs' engagement and their passive role in policymaking may be observed when looking at the frequency of the strategies employed during the decision-making process. The use of different techniques is dispersed; in 


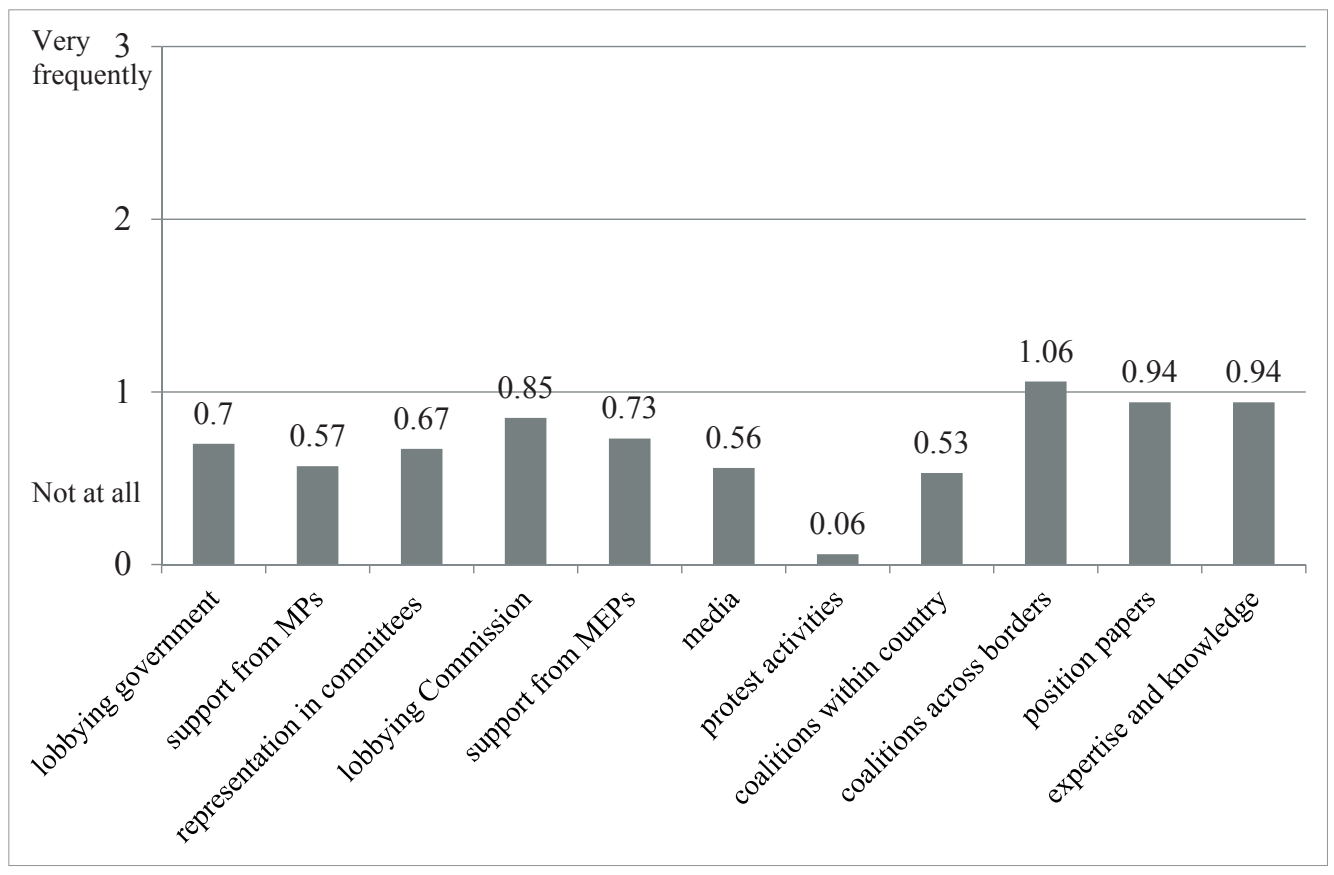

Figure 4: Strategies of non-state stakeholders, the view of national officials (mean values)

Source: INTEREURO survey, 35 interviews with national officials

fact, each technique is rarely used. To a slightly bigger extent, CSOs rely on building coalitions with foreign organizations, creating an extensive body of technical expertise and knowledge, and publishing position papers. But even these strategies are not often employed.

\section{Conclusion}

Forming national positions on EU legislation is an important phase of the policy process for any Member State by allowing a country to express its expectations and intentions concerning new legislation. Based on the position adopted, countries then negotiate on the final version of EU legislation. In the process of forming national positions on proposed EU legislation, CSOs should be included. First, the representatives of CSOs can bring in expert knowledge and experience not possessed by civil servants yet important for the country. Second, they represent a bridge between the public and decision-makers that contributes to more legitimate and democratic decisions.

Slovenia seems to neglect the expertise and information held by CSOs in the process of forming its national positions. The current system for coordinating EU affairs does not anticipate any role for CSOs. The national position is typically formed at a lower bureaucratic level in such a way that it is based on the Commission's proposal, thereby avoiding any bigger changes to national legislation and remaining sufficiently broad to enable negotiations. The role of the National Assembly (a representative 
body of citizens) is minor and passive. National officials, on the other hand, recognize the benefits of including CSOs in the whole process but are afraid of greater work, more bureaucratic processes, and corruption (for the latest, see also Radu, 2017). At the same time, CSOs also remain quite passive. Recently, some changes have been noticed due to the individual engagement of policy officials and certain competent authorities. One advance is the public availability at least of a few documents via the EU portal. In the future, more systematic rules to ensure the inclusion of CSOs in EU policymaking at the national level should be prepared.

Although greater changes and progress concerning the inclusion of civil society in EU policymaking at the national level have often been limited by the shortage of staff, economic crises, absence of new employment and work overload due to big events like accession to the EU (2004), adopting the common currency Euro (2007), accession to the Schengen Area (2007) and the presidency (2008), after 15 years of EU membership, during which time EU affairs have become interiorized, the national process of EU policymaking is still far from ideal. Criticism can be expressed at all levels. At the political level, a clear and forward-thinking national strategy of goals and interests concerning the EU should be adopted. At the civil servants' level, the significance of EU legislation should be better recognized, along the maximum inclusion of CSOs in the process of formulating national positions on proposed EU legislation. At the level of CSOs, greater professionalization, higher quality staff and a proactive approach are needed.

Although the article analyzed the case study of Slovenia, the research results can be highly relevant for other EU Member States mostly from Central and Eastern Europe. These countries all have in common a socialist past, delayed development of the civil society sector, and represent newer EU members. For the increase of legitimacy of national positions presented in the Council of the EU, it is necessary to give a clear role to CSOs in the coordination of EU affairs especially when and where civil society is still in the process of developing. We recommend the preparation of guidelines for national officials on how to bring CSOs in forming national positions, as well as the introduction of more transparency in the process of adopting national positions.

Acknowledgements: The analysis is based on research as part of the international project INTEREURO (www.intereuro.eu; also see Beyers et al., 2014), conducted under the auspices of the European Science Foundation, and financially supported by the Slovenian Research Agency under Grants N5-0014 and P5-0136. The analysis is also based on research by the Ministry of Foreign Affairs, Directorate for EU Affairs, in the framework of the project 'Improving consultation practices in decision-making on EU affairs at the national level among key actors in EU policymaking at national level'. We wish to give special thanks for providing us with the data. The authors would also like to thank the participants at the 'Governing Across Jurisdictions' panel at the IPSA 2016 World Congress for all their useful comments and suggestions. 


\section{References:}

1. Act on Cooperation between the National Assembly and the Government in EU Affairs, 2010, Official Journal of the Republic of Slovenia, No. 34/2004, No. 43/2010, No. 107/2010.

2. Austen-Smith, D. and Wright, R.J., 'Competitive Lobbying for a Legislator's Vote', 1992, Social Choice and Welfare, vol. 9, no. 3, pp. 229-257.

3. Beyers, J., 'Gaining and Seeking Access: The European Adaptation of Domestic Interest Associations', 2002, European fournal of Political Research, vol. 41, no. 5, pp. 585-612.

4. Beyers, J., Chaqués Bonafont, L., Dür, A., Eising, R., Fink-Hafner, D., Lowery, D., Mahoney, C., Maloney, W. and Naurin, D., 'The INTEREURO Project: Logic and Structure', 2014, Interest Groups \& Advocacy, vol. 3, no. 2, pp. 126-140.

5. Börzel, T., 'Why You Don't Always Get What You Want: EU Enlargement and Civil Society in Central and Eastern Europe', 2010, Acta Politica, vol. 45, no. 1, pp. 1-10.

6. Črnak-Meglič, A. and Rakar, T., 'The Role of the Third Sector in the Slovenian Welfare System', 2009, Teorija in praksa, vol. 46, no. 3, pp. 237-254.

7. Dimitrova, A. and Toshkov, D., 'The Dynamics of Domestic Coordination of EU Policy in the New Member States: Impossible to Lock In?', 2007, West European Politics, vol. 30, no. 5, pp. 961-986.

8. Dye, T.R., Understanding Public Policy, Englewood Cliffs, NJ: Prentice-Hall, 1972.

9. European Commission, European Governance - A White Paper, COM (2001) 428 final, published in the Official Journal of the European Union No. C 287/1 from 12.10.2001.

10. Fink-Hafner, D. and Lajh, D., Proces evropeizacije in prilagajanje političnih ustanov na nacionalni ravni [The Process of Europeanisation and the Adaptation of Political Institutions at National Level], Ljubljana: Fakulteta za družbene vede, 2005.

11. Fink-Hafner, D. and Lajh, D., 'The 2008 Slovenian EU Presidency: A New Synergy for Europe?, Stockholm: Swedish Institute for European Policy Studies, 2008, [Online] available at https://www.sieps.se/en/publications/2008/the-2008-slovenian-eu-presidency-a-new-sy nergy-for-europe-20082op/Sieps-2008_2op.pdf?, accessed on August 30, 2020.

12. Fink-Hafner, D., 'Europeanization in Managing EU Affairs: Between Divergence and Convergence, a Comparative Study of Estonia, Hungary and Slovenia', 2007, Public Administration, vol. 85, no. 3, pp. 805-828.

13. Gärtner, L., Hörner, J and Obholzer, L., 'National Coordination of EU Policy: A Comparative Study of the Twelve 'New' Member States', 2011, fournal of Contemporary European Research, vol. 7, no. 1, pp. 77-100.

14. Geuijen, K. and Hart, P., 'Flying Blind in Brussels: How National Officials Do European Business Without Political Steering', in Colebatch, H.K., Hoppe, R. and Noordegraaf, M. (eds.), Working for Policy, Amsterdam: Amsterdam University Press, 2010, pp. 171-190.

15. Hogwood, B. and Gunn, L., Policy Analysis for the Real World, Oxford, New York: Oxford University Press, 1984.

16. Kassim, H., 'Introduction: Coordinating National Action in Brussels', in Kassim, H., Menon, A., Peters, G.B. and Wright, V. (eds.), The National Co-ordination of EU Policy: The European Level, Oxford, New York: Oxford University Press, 2001, pp. 1-46.

17. Koeppl, P., 'The Acceptance, Relevance and Dominance of Lobbying the EU Commission: A First-time Survey of the EU Commission's Civil Servants', Journal of Public Affairs, 2001, vol. 1 , no. 1, pp. 69-80. 
18. Krašovec, A. and Lajh, D., 'Specialisti za zadeve Evropske unije in njihova vloga v volilnih procesih' [Specialists in European Union Affairs and Their Role in Electoral Processes], in Krašovec, A., Volitve v Evropski parlament 2009 [Elections for European Parliament 2009], Ljubljana: Fakulteta za družbene vede, 2010, pp. 117-140.

19. Lajh, D., 'Spreminjanje institucionalnega ravnotežja in demokratični primanjkljaj v Evropski uniji' [Changing the Institutional Balance and the Democratic Deficit in the European Union], in Fink Hafner, D. (ed.), Evropske stranke in strankarski sistem na ravni Evropske unije [European Parties and the Party System at the European Union Level], Ljubljana: Fakulteta za družbene vede, 2004, pp. 43-65.

20. Lajh, D., 'The Executive Co-ordination of the Slovenian EU Presidency: An Honest Broker', in Drulák, P. and Šabič, Z. (eds.), The Czech and Slovenian EU Presidencies in a Comparative Perspective, Dordrecht: Republic of Letters, 2010, pp. 111-126.

21. Lajh, D., 'Twenty Years of Relations between the Republic of Slovenia and the European Union', 2012, Studia Historica Slovenica, vol. 12, no. 1, pp. 125-146.

22. MZZ, Coordination of European Affairs (Ministry of Foreign Affairs, Coordination of European Affairs). 2016, [Online] available at http://www.mzz.gov.si/si/evropske_politike/ koordinacija_evropskih_zadev/, accessed on June 29, 2016.

23. MZZ, Directorate for EU Affairs (Ministry for Foreign Affairs, Directorate for EU Affairs), Survey on the Advisory Practice in the Establishment of National Positions in Decision-Making on EU Affairs, 2015.

24. MZZ, Position Preparation Procedure (Ministry of Foreign Affairs/ Position Preparation Procedure), 2016, [Online] available at http://www.mzz.gov.si/si/evropske_politike/priprava_stalisc_slovenije_v_zadevah_eu/, accessed on June 29, 2016.

25. Po-DZ-1 (Rules of Procedure of the National Assembly), Official Journal of the Republic of Slovenia, No. 92/2007.

26. Parsons, W., Public Policy: An Introduction to the Theory and Practice of Policy Analysis, Aldershot, Brookfield: Edward Elgar, 1995.

27. Princen, S., Agenda-Setting in the European Union, Houndmills, Basingstoke, Hampshire: Palgrave Macmillan Richardson, 2009.

28. Radu, L., 'Corruption in the European Union and the Responsibility of European Institutions', 2017, Transylvanian Review of Administrative Sciences, no. 50E, pp. 164-176.

29. ReNDej (Resolucija o normativni dejavnosti) [Resolution on Legislative Regulation], Official Journal of the Republic of Slovenia, No. 95/2009.

30. Richardson, J., European Union: Power and Policy-Making, New York: Routledge, 2006.

31. Rules of Procedure of the Government of the Republic of Slovenia, Official Journal of the Republic of Slovenia, No. 43/01, 23/02, 54/03, 103/03, 114/04, 26/06, 21/07, 32/10, 73/10, 95/11, 64/12, 10/14.

32. Saurugger, S., 'Interest Groups and Democracy in the European Union', 2008, West European Politics, vol. 31, no. 6, pp. 1274-1291.

33. Stakeholder meeting, Demokratizacija in učinkovitost procesov oblikovanja stališč RS do EU politik [Democratization and Efficiency of the Processes of Creating Positions Republic to EU Policies], Ljubljana: Center za politološke raziskave, May 6, 2015b.

34. Stakeholder meeting, Koordinacija EU zadev in vloga slovenskih igralcev pri oblikovanju EU politik, spremembe skozi čas in vpliv evropeizacije [Coordination of EU Affairs and the 
Role of Slovenian Players in Shaping EU policies, Changes Over Time and the Impact of Europeanization], Ljubljana: Center za politološke raziskave, January 22, 2015a.

35. TFEU (Treaty on the Functioning of the European Union), published in the Official Journal of the European Union No. C 326/1 from 26.10.2012.

36. UZ3a, 47, 68 (Constitutional Act amending Chapter 1 and Articles 47 and 68 of the Constitution of the Republic of Slovenia), 2003, Official Journal of the Republic of Slovenia, No. 24/2003.

37. Wallace, H., 'An Institutional Anatomy and Five Policy Modes', in Wallace, H., Pollack, M.A and Young, A.R. (eds.), Policy-Making in the European Union, Oxford, New York: Oxford University Press, 2010, pp. 69-104.

38. Young, A.R., 'The European Policy Process in Comparative Perspective', in Wallace, H., Pollack, M.A and Young, A.R. (eds.), Policy-Making in the European Union, Oxford, New York: Oxford University Press, 2010, pp. 45-68.

39. ZintPK (Zakon o integriteti in preprečevanju korupcije) [Integrity and Prevention of Corruption Act], Official Journal of the Republic of Slovenia, No. 69/2011.

40. Žurga, G., 'Project Management in Public Administration. TPM - Total Project Management Maturity Model. The Case of Slovenian Public Administration', 2018, Transylvanian Review of Administrative Sciences, 53E, pp. 144-159. 